\title{
Opinions and attitudes of some parents in Ilorin, north-central Nigeria, towards child abuse and neglect
}

Folorunsho Tajudeen Nuhu, MB BS, FMCPsych

Child and Adolescent Psychiatry Unit, Federal Neuropsychiatric Hospital, Barnawa, Kaduna State, Nigeria

Sinat Taiwo Nuhu, RN, RPN

Kwara State School of Nursing, Kwara State, Ilorin, Nigeria

Background. The few studies on child abuse in Nigeria have focused on the child victims. However, little is known about characteristics of the parents who are the perpetrators of this abuse.

Aim. To assess the opinions and attitudes of parents concerning child abuse and neglect, and the factors associated with the practice of child abuse.

Method. We interviewed 260 randomly selected parents in the city of Ilorin, Nigeria, using a questionnaire to ascertain socio-demographic data and details about the understanding and practice of various forms of child abuse such as hawking, child labour, physical beating, sending children to work as house-helps, and sexual abuse.

Results. Sixty per cent of the subjects were women, and $72.7 \%$ were less than 40 years old; $30.4 \%$ sent their children to hawk goods, $34.2 \%$ believed that a child must work before receiving food, $10.4 \%$ had sent or would send their children to work as house-helps, and $52.3 \%$ discipline their children by physical beating. Older age 140 years and over), being unmarried, being unemployed, having 3 or more children, and a low level of education were significantly associated with the tendency to abuse children.

Conclusion. Child abuse is still practised in Ilorin, Nigeria. Socio-economic factors associated with child abuse were identified. We recommend that government should assist citizens financially and support programmes that educate parents about the dangers of child abuse.
Nigeria has a population of 140 million people; ${ }^{1}$ about $45 \%$ of them are under the age of 15 years. ${ }^{2}$ The country is the world's sixth-largest oil exporter, yet $54 \%$ of its citizens live below the poverty line.' The country is wealthy but the people are poor. ${ }^{3}$

It is therefore not surprising that a substantial proportion of the population are faced with significant financial difficulties. This abject poverty has led to various survival ploys that abuse children, such as child labour, hawking, begging, ${ }^{3}$ children working as house-helps, ${ }^{4}$ and in some cases sending away children for adoption to live with and work for better-off relatives or friends, who may give preferential treatment to their own children. ${ }^{5}$

Brutal cultural behaviour le.g. children are flogged or severely beaten for even minor misdemeanours ${ }^{6}$ as a way of 'teaching' them) also contributes to the unhealthy conditions for children.

In some parts of the country, children are made to fend for themselves. A typical example is the Almajiri children in the northern parts of the country. These children are given to an Islamic teacher called a Mallam, ostensibly to live with him and learn the teachings of Islam. They are, however, required to go out and beg for money, food and other alms. ${ }^{4,7}$ Sometimes the children are seen as early as 6.30 a.m., even during the harmattan period when the weather is very cold and dry. The proceeds of their efforts must be returned to the teacher. Some children are forced to lead handicapped adult beggars about on the streets. ${ }^{4}$ These things happen at an age when the children are supposed to be at school, and are in stark contrast to the Child's Rights Act which states that a child shall not be used to beg for alms, guide beggars, hawk goods, or for any purpose that deprives the child of the opportunity to attend and remain in school. ${ }^{8}$

Studies in Nigeria have shown that sexual abuse of children is prevalent in the country, and is under-reported. ${ }^{9}$ Olley reported a child sexual abuse (CSA) incidence of $55 \%$ among a sample of school-going adolescents in Ibadan, south-west Nigeria. There have been few reports of CSA on national television. However, it has been reported to be associated with various problems in adulthood, which include substance abuse, suicide, depression, sexual dysfunction and personality problems..$^{10-14}$ 
The few studies on child abuse in Nigeria have focused on the victims rather than the perpetrators, who are generally adults and often the parents of the afflicted children. Little is known about the opinions of the parents on child abuse in the northern parts of the country as there is a dearth of literature on this matter. We therefore conducted the present study to address the issue in this part of the country.

\section{Objectives}

Our aim was to assess the opinions and attitudes of subjects concerning child abuse and neglect, and identify sociodemographic factors associated with child abuse.

\section{Study design and population}

This was a cross-sectional study carried out among the residents of Oja-Oba community in the llorin-West local government area of Kwara State in northern Nigeria. It is representative of other districts in this area, and represents people of different social classes.

In the absence of a recent, detailed household census, we estimated by direct counting, with the help of some locals, that there were 672 households in the community. We selected the subjects using a systematic sampling technique by choosing every third person of the household. We interviewed one parent in a family; where both parents were present, we asked the couple to choose one of them by consensus. Where there was more than one family in a household, we interviewed one parent from each family. We excluded all those who refused to give consent. In all, 260 subjects participated in the study.

\section{Measurements}

Subjects were interviewed using a questionnaire designed by the authors. The questionnaire had 2 sections: a socio-demographic section and a child abuse section. The items in the second section included questions about hawking, methods for correcting the child, child labour, and sending the child to work as a househelp. Other questions concerned the provision of basic needs and school items, reasons for abusing/neglecting the child, and possible solutions to child abuse/neglect problems. The design of the questionnaire was based on the authors' personal experience while working in the child and adolescent psychiatric clinics of the University College Hospital, Ibadan and the Federal Neuropsychiatric Hospital in Kaduna, Nigeria, and a review of previous studies of child abuse and neglect. We administered the instruments to 20 randomly selected adults in the area and repeated the exercise 2 weeks later to determine the internal consistency of the questionnaire items (Cronbach's $\alpha 0.724$; interitem correlation 0.116 ). These 20 subjects were not included in the study.

The Kwara State Ministry of Health gave approval for the study, and the participants gave informed consent. A total of 17 parents refused the interview. Five of them said they had an appointment elsewhere which could not be sacrificed for our study, 8 women said they would not participate without the permission of their husbands who had travelled away from llorin during the time of interview, 1 woman said we were agents of the government, and the remaining 3 gave no reason for their refusal.

\section{Statistical analysis}

Version 13 of the Statistical Package for Social Sciences (SPSS-13) software was used for analysis. Descriptive statistics were calculated for the variables, which included means and standard deviation. Frequency distribution and cross-tabulations were generated, the ttest and chi-square $\left(\chi^{2}\right)$ test were used to investigate associations between various forms of child abuse, and continuous and categorical variables respectively and multiple logistic regression analysis were used to determine the true associations between socio-demographic variables and various forms of child abuse. A p value of $<0.05$ was taken as statistically significant.

\section{Results}

\section{Socio-demographic characteristics}

The socio-demographic characteristics of the subjects are shown in Table I. About 73\% of the subjects were below the age of 40 years, $60 \%$ were female, $7 \%$ were unemployed and $37 \%$ were either separated, divorced or widowed. About $11 \%$ had no formal education, and 30\% earned more than N20 000 a month.

One hundred and forty-seven (56.5\%) subjects recognised that beating a child excessively, sending a child to hawk goods, starving a child, early exposure of a child to sex, and neglecting the child's educational, basic and health needs are various forms of child abuse/neglect.

\section{Forms of child abuse}

Seventy-nine (30.4\%) subjects admitted that they send their children to hawk goods on streets and highways. Older parents 


\begin{tabular}{|c|c|c|}
\hline Variables & $\begin{array}{l}\text { Frequency } \\
\text { (N) }\end{array}$ & $\begin{array}{c}\text { Percentage } \\
\text { (\%) }\end{array}$ \\
\hline \multicolumn{3}{|l|}{ Age } \\
\hline$<40$ years & 189 & 72.7 \\
\hline$\geq 40$ years & 71 & 27.3 \\
\hline \multicolumn{3}{|l|}{ Gender } \\
\hline Male & 104 & 40.0 \\
\hline Female & 156 & 60.0 \\
\hline \multicolumn{3}{|l|}{ Religion } \\
\hline Islam & 142 & 54.6 \\
\hline Christianity & 118 & 45.4 \\
\hline \multicolumn{3}{|l|}{ Occupation } \\
\hline Civil servant & 89 & 34.3 \\
\hline Self-employed & 153 & 58.8 \\
\hline Unemployed & 18 & 6.9 \\
\hline \multicolumn{3}{|l|}{ Marital status } \\
\hline Married & 164 & 63.1 \\
\hline Not married & 96 & 36.9 \\
\hline \multicolumn{3}{|l|}{ Children } \\
\hline$\leq 2$ & 91 & 35.0 \\
\hline$\geq 3$ & 169 & 65.0 \\
\hline \multicolumn{3}{|l|}{ Education } \\
\hline Nil & 28 & 10.8 \\
\hline Primary & 72 & 27.7 \\
\hline Secondary & 130 & 50.0 \\
\hline Tertiary & 30 & 11.5 \\
\hline \multicolumn{3}{|l|}{ Income } \\
\hline Nil & 11 & 4.2 \\
\hline$<\mathrm{N} 20000$ & 173 & 66.2 \\
\hline N20 000 - N50 000 & 70 & 27.2 \\
\hline$>\mathrm{N} 50000$ & 6 & 2.4 \\
\hline
\end{tabular}

( $p<0.001)$, those who are unemployed ( $p=0.020)$, those who are not married (divorced, separated, widowed, never married) $(p=0.014)$, those who had $\geq 3$ children $(p<0.001)$, and those with a low level of education $(p<0.001)$ and low income $(p<0.01)$ were significantly associated with sending children to sell goods (Table II).

In addition to hawking, children are used as labour, e.g. working on farms, carrying goods, and cleaning shops. Sometimes this work is done during school hours. Eighty-nine (34.2\%) parents said that children must work before being fed or given their basic needs. Parents who were old (>40 years of age), unemployed and not married $(p<0.001)$, and those who had at least 3 children and a low education $(p<0.001)$ and low income ( $p<0.02$ ) were significantly more likely to believe that a child must work (Table II).

Twenty-seven (10.4\%) respondents said they could send or have sent their children to work as house-helps. There was no statistically significant difference in terms of age, gender, marital status, occupational status, income and education between those who could and those who could not send their children to work as housemaids/boys ( $p>0.05$ ).

One hundred and thirty-six (52.3\%) parents reported that they beat their children to correct unwanted or unacceptable behaviour. They described it as 'gentle beating' - but the sense of what constituted a gentle beating ranged over flogging, giving a 'few' strokes of the cane, and a 'gentle' slap. Some respondents, however, admitted that sometimes they were unable to regulate the extent of beating. Being old $(p=0.028)$, or unemployed $(p=0.002)$, and of low education ( $p<0.05)$ were significantly associated with disciplining a child by beating (Table II).

After logistic regression analysis, older age, unemployment, higher number of children and low education were predictive of sending children to hawk. In addition to these correlations, being unmarried predicted the use of children as labour; while older age, unemployment and low education were predictive of beating a child to correct unwanted behaviour (Table III).

Only $7(2.7 \%)$ of our subjects admitted that their children had been sexually abused. They added that adults who were not members of the family were involved in these acts. None of these subjects reported the incidents to the police because they did not want their children to be stigmatised. Three (1.2\%) women said that they could give their daughters away for marriage before the age of 18 years if their husbands agreed to such an arrangement, but all respondents said they would not encourage their children to involve themselves in illicit sexual behaviour for any reason.

All the respondents denied ever asking their children to guide beggars on the street.

Ninety-six per cent of the parents reported that they provided their children with basic educational and health needs, and 90\% believed that both parents should be involved in the care of their children.

Respondents recognised the following factors as causes of child abuse/neglect: single parenthood (80.4\%), poverty/ unemployment (72.3\%), cultural factors/lack of education (26.2\%), and the child being stubborn or difficult (1.2\%). About $52 \%$ suggested that the government should provide jobs and improve the economy, $42 \%$ wanted the government to provide free education, while only $5.8 \%$ said that there should be legislation against child abuse. 


\begin{tabular}{|c|c|c|c|}
\hline Variables & Hawking N (\%) & Child labour N (\%) & Beating $N(\%)$ \\
\hline \multicolumn{4}{|l|}{ Age } \\
\hline$<40$ yrs & $43(22.8)$ & $50(26.5)$ & $91(48.1)$ \\
\hline$\geq 40$ yrs & $36(50.7)$ & $39(54.9)$ & $45(63.4)$ \\
\hline Gender & $\chi^{2}=20.298^{*}$ & $\chi^{2}=19.947^{\dagger}$ & $\chi^{2}=9.704^{\ddagger}$ \\
\hline Male & $31(29.8)$ & 33 (31.7) & $54(51.9)$ \\
\hline Female & $48(30.8)$ & $56(35.9)$ & $82(52.6)$ \\
\hline Religion & $\chi^{2}=0.027$ & $\chi^{2}=0.481$ & $\chi^{2}=1.506$ \\
\hline Islam & $37(26.1)$ & $49(34.5)$ & $74(52.1)$ \\
\hline Christianity & $42(35.6)$ & 40 (33.9) & $62(52.5)$ \\
\hline Occupation & $\chi^{2}=2.111$ & $\chi^{2}=0.011$ & $\chi^{2}=1.228$ \\
\hline Civil servant & $18(20.2)$ & $14(15.7)$ & $39(43.8)$ \\
\hline Self-employed & 50 (32.7) & $64(41.8)$ & 81 (52.9) \\
\hline Unemployed & $11(61.1)$ & $11(61.1)$ & $16(88.9)$ \\
\hline Marital status & $12.759 *$ & $\chi^{2}=23.232^{\dagger}$ & $\chi^{2}=13.034^{\ddagger}$ \\
\hline Married & $41(25.0)$ & $43(26.2)$ & 57 (41.9) \\
\hline Unmarried & $38(39.6)$ & $46(47.9)$ & $79(48.2)$ \\
\hline Children & $\chi^{2}=6.088^{\ddagger}$ & $\chi^{2}=12.662^{\dagger}$ & $\chi^{2}=5.08$ \\
\hline$\leq 2$ & $6(6.6)$ & $16(17.6)$ & $51(56.0)$ \\
\hline \multirow[t]{2}{*}{$\geq 3$} & $7(43.2)$ & $73(43.2)$ & $85(50.3)$ \\
\hline & $\chi^{2}=39.998^{\dagger}$ & $18.678^{\dagger}$ & $\chi^{2}=2.291$ \\
\hline Mean years of education (MYE) & $t=3.435^{\dagger}$ & $t=3.637^{\dagger}$ & $t=2.267^{\ddagger}$ \\
\hline Mean income (MI) & $t=2.556^{\ddagger}$ & $t=2.281^{\ddagger}$ & $t=1.577^{\ddagger}$ \\
\hline 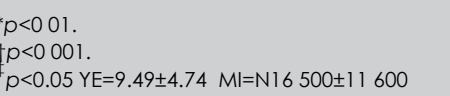 & & & \\
\hline
\end{tabular}

\section{Discussion}

Only $29.6 \%$ of our subjects earned more than N20 000 labout US\$168) per month. This finding is similar to an earlier report on the population of Nigeria. 'This low income has to cater for the parents and their children. Most parents had at least 3 children.

About $30 \%$ of parents send their children to hawk goods, which is in keeping with earlier reports. 315 This is understandable in view of the level of poverty. Parents reported that they needed to do this in their struggle to survive. Older parents were more likely to send children to engage in street trading, possibly because they had more children and consequently more financial load. In our study, all parents $\geq 40$ years old had $\geq 3$ children. Those who were unemployed tried to obtain income from their children's efforts, using the income for themselves and the children. Parents with a low level of education were largely unemployed. Street trading has dangerous consequences. Some children are knocked down by vehicles and injured, ${ }^{4}$ some are lured by adults into sexual acts, ${ }^{16}$ and some are tricked into taking psychoactive substances.

Child labour is similar to hawking. Thirty-four per cent of the parents believed that a child must work before being fed or given basic needs. Their reasons were to prevent the child from becoming a 'lazy adult' and to teach him how to live an independent life should the parents die. The factors associated with this opinion are similar to those of street trading and hawking. It is common practice for parents to train children how to be independent. However, it is improper for parents to engage their children in any trade or activity that prevents them from attending school.

Older parents were more likely to use beating as a disciplinary method because of the cultural belief that children can only 


\begin{tabular}{|c|c|c|c|}
\hline Parental variables & $p$-value & OR & $95 \% \mathrm{Cl}$ \\
\hline \multicolumn{4}{|l|}{ Hawking } \\
\hline Older age* & 0.003 & 0.194 & $0.065-0.574$ \\
\hline Unemployed* & 0.043 & 0.059 & $0.004-0.914$ \\
\hline Unmarried & 0.065 & 2.293 & $0.950-5.537$ \\
\hline$\geq 3$ children* & $<0.001$ & 0.015 & $0.003-0.880$ \\
\hline Low education* & 0.012 & 2.038 & $1.166-3.563$ \\
\hline Low income & 0.128 & 1.551 & $0.881-2.728$ \\
\hline \multicolumn{4}{|l|}{ Child labour } \\
\hline Older age* & 0.004 & 0.221 & $0.080-0.613$ \\
\hline Unemployed* & 0.021 & 0.090 & $0.012-0.696$ \\
\hline Unmarried* & 0.001 & 3.688 & $1.650-8.245$ \\
\hline$\geq 3$ children* & 0.002 & 0.206 & $0.077-0.553$ \\
\hline Low education* & $<0.001$ & 3.135 & $1.803-5.451$ \\
\hline Low income & 0.744 & 1.089 & $0.625-1.931$ \\
\hline \multicolumn{4}{|l|}{ Correction } \\
\hline Older age* & 0.009 & 3.374 & $1.355-8.401$ \\
\hline Unemployed & 0.112 & 5.192 & $0.680-39.618$ \\
\hline$\geq 3$ children* & 0.015 & 0.373 & $0.169-0.824$ \\
\hline Low education* & $<0.001$ & 0.382 & $0.220-0.645$ \\
\hline Low income & 0.262 & 0.733 & $0.426-1.262$ \\
\hline $\begin{array}{l}\text { dds ratio (OR) p value an } \\
\text { statistically significant. }\end{array}$ & nce interv & ther vari & \\
\hline
\end{tabular}

learn 'when there is a cane'; a Yoruba proverb goes: 'A cane is the medicine for correcting a child's misdeeds.' A low level of education is also a factor in physical beatings. More parents aged $\geq 40$ had a lower level of education, compared with younger parents $\left(\chi^{2}\right.$ 50.784; $\left.p<0.001\right)$. It is possible that those who have a higher level of education have a better understanding of how to correct mistakes. As many as $52 \%$ of our respondents employed physical beating; as mentioned earlier, many of them admitted that sometimes they lost control when beating their children. Such loss of control has led to child battering and severe injuries and physical disabilities. The national TV station (NTA) has shown children with bruises, burns and missing limbs as a result of beatings and physical assaults by adults who claimed that they were teaching the children morals. It is disturbing to note that these children were often punished for such minor misdeeds as forgetting to fetch water, stealing a piece of meat, and not returning home 'early'. Ebigbo ${ }^{16}$ and Olaleye ${ }^{6}$ reported that severe punishment was applied in Nigeria both for minor misdemeanours and serious offences, and is culturally approved in this part of the world. But it is not as effective as positive reinforcement, and there is a tendency for the child to react with aggressive behavior. ${ }^{18}$ It is therefore more desirable to adopt a method of behaviour modification which is safer and more effective, to correct unwanted behaviour.
As many as $10 \%$ of the parents have sent (or can send) their children to work as housemaids or houseboys. These children are expected to generate income for the whole family; while doing so, they are deprived of the opportunity to attend school or learn a trade. Children as young as 7 years have been sent out to work as housegirls. ${ }^{19}$

The fact that only $7(2.7 \%)$ parents reported that their children have been sexually abused suggests that CSA is under-reported. In addition, none of our subjects admitted that they had been involved in any form of sexual abuse of their children. ${ }^{9}$ Olley interviewed 2290 school-going adolescents in Ibadan, Nigeria, and found a $55 \%$ prevalence of CSA among them. He also reported that $36 \%$ of the abuse occurred within the family. It is possible that parents are not aware of such abuse because the children do not report it - a child may be reluctant to disclose sexual abuse because of societal taboos against sexual behaviour ${ }^{20}$ or stigma associated with being sexually abused. ${ }^{4}$ Another possibility is that the parents in our study deliberately withheld knowledge of CSA, even when it had occurred.

\section{Conclusion}

Our findings suggest that, even though many parents have a good understanding of what constitutes child abuse, they are still 
compelled by socio-economic and cultural factors to indulge in such abuse. Our study shows that child abuse is rampant in our society; the perpetrators acknowledge that it is a problem but they don't seem to realise the magnitude of the problem. However, they recognised that socio-economic and cultural factors are contributory.

We therefore suggest that government should empower its citizens financially by providing job opportunities and free education for children, and supporting all programmes such as seminars and conferences that address the psychosocial and educational needs of children. There should also be awareness programmes throughout the media to educate parents about the consequences of child abuse.

\section{Limitations}

Our study was carried out in one part of the country. A nationwide survey will be more generalisable. The instrument used was designed for the purpose of this study, and has not been validated comprehensively.

\section{References}

1. Nigerian Population Census, 2006. Abuja: National Population Commission.

2. Nigerian Population Census, 1991. Abuja: National Population Commission.

3. UNICEF. Regional consultation on child labour exploitation in West and Central Africa (UNICEF/ILO). Abidjan: Review of research findings in Nigeria. Presented by UNICEF NIGERIA 10 - 13 July 1996.
4. Ebigbo PO. Street children: The core of child abuse and neglect in Nigeria. Children, Youth and Environment 2003; 13: 1-12

5. Omigbodun $\mathrm{O}$, Olatawura MO. Child-rearing practices in Nigeria: Implications for mental health. Nigerian Journal of Psychiatry 2008; 6:1 0-15.

6. Olaleye $\bigcirc$. Cultural diversity, child discipline and child right convention: the quest for 'universal child'. J Private Bus Law 2005; 4: 162-182.

7. Suleiman GT, Adeyemi SO, Adeponle AB. An overview of psychoactive substance use and misuse in Northern Nigeria. Nigerian Journal of Psychiatry 2006; 4: 9-14

8. Alemika EEO, Chukwuma I, Lafratta D, Messerli D, Souckova J. A report prepared for the Committee on the Rights of the Child, 38th session, January 2005, Geneva.

9. Olley BO. Prevalence of child sexual abuse among some in-school adolescents in Ibadan, south-west, Nigeria. Paper presented at the Conference of the Association of Psychiatrists in Lagos, Nigeria, November 2007

10. Mullen PE, Martin JL, Anderson JC, Romanus SE, Herbison GP. Childhood sexual abuse and mental health in adult life. Br J Psychiatry 1993; 163: 721-732.

11. Osofsky JD. The impact of violence on children. Future Child 1999; 9: 33-49.

12. Heffernan K, Cloitre M, Tardiff K, Marzuk PM, Portera L, Leon AC. Childhood trauma as a correlate of lifetime opiate use in psychiatric patients. Addiction Behav 2000; 25: 797-803.

13. Hill J, Pickles A, Burnside E, et al. Child sexual abuse, poor parental care and adult depression: Evidence for different mechanisms. Br J Psychiatry 200 1; 179: 104-109.

14. Duber SR, Felitti VJ, Dong M, Chapman DP, Giles WH, Anda RF. Childhood abuse, neglect and household dysfunction, and the risk of illicit drug use: the adverse childhood experience study. Paediatrics 2003; 111 : 564-572.

15. Bamgbose $\bigcirc$. Teenage prostitution and the future of the female adolescent in Nigeria. Int J Offender Ther Comp Criminol 2002; 46: 569-585

16. Ebigbo PO, Abaga S. Sexual experience of street trading girls in the city of Enugu. ISPCAN - 8th International Congress on Child Abuse and Neglect, September 1990, Hamburg, Germany.

17. Ebigbo PO. Child abuse and neglect in Nigeria - a situation analysis. Nigeria's Population: Quarterly Journal of Population Activities in Nigeria 1993; 10: 4.

18. Shaddock JB, Shaddock AV. Learning theories. In: Kaplan and Shaddock's Synopsis of Psychiatry. 10th ed. London: Lippincott Williams and Wilkins, 2007: 145.

19. Omigbodun 00 . Psychosocial issues in a child and adolescent psychiatric clinic population in Nigeria. Soc Psychiatry Psychiatr Epidemiol 2004; 39: 667-672.

20. Obiako MN. Sexual Abuse of Children: The Nigerian Styles. African Network for the Prevention and Protection against Child Abuse and Neglect (ANPPCAN) Launch. Abuja, Nigeria: October/November 1986. 